\title{
Education, Culture and Heritage: A Proposal for Use of YouTube Videos in High School
}

\author{
Glauco Ricciele P. L. C. Ribeiro1, Luci M. M. Bonini², Francisco Carlos Franco3 ${ }^{3}$ Rosália Maria N. Prados ${ }^{4}$ \\ ${ }^{1}$ Technical School Etec, Mogi das Cruzes, São Paulo, Brazil \\ ${ }^{2}$ University of Mogi das Cruzes and Technological Research Institute of São Paulo, São Paulo, Brazil \\ ${ }^{3}$ University Braz Cubas, Mogi das Cruzes, São Paulo, Brazil \\ ${ }^{4}$ University of Mogi das Cruzes, São Paulo, Brazil \\ Email: lucibonini@gmail.com
}

How to cite this paper: Ribeiro, G. R. P. L. C., Bonini, L. M. M., Franco, F. C., \& Prados, R. M. N. (2016). Education, Culture and Heritage: A Proposal for Use of YouTube Videos in High School. Creative Education, 7, 2640-2651.

http://dx.doi.org/10.4236/ce.2016.717248

Received: September 27, 2016

Accepted: November 13, 2016

Published: November 16, 2016

Copyright $\odot 2016$ by authors and Scientific Research Publishing Inc. This work is licensed under the Creative Commons Attribution International License (CC BY 4.0).

http://creativecommons.org/licenses/by/4.0/

\begin{abstract}
This paper described a new teaching methodology based on the use of social networking of YouTube videos. It was developed with high school students in a Technological High School-ETEC President Vargas, in Mogi das Cruzes, São Paulo, Brazil. The students were invited to develop critical appointments about the cityscape, unveil the simplest cultural heritage of everyday life. After this they created a channel on YouTube called Citizenship Dialogue, in which 31 videos are available until present date. This research was based on contemporary studies of communication and heritage education. It was a qualitative approach, which described the actions these boys and girls developed along the year of 2014. The results show that one can apply this methodology based on communication and education because the product - the video language reflects a critical overview of everyday life of these participants.
\end{abstract}

\section{Keywords}

Basic Education, Heritage Education, Local Culture

\section{Introduction}

The cultural and economic integration supported by the improvement of social media triggered new forms in the organization and centralization of capital. This factor favored the constitution of new settings of injustices and inequalities, which exacerbated even more poverty, exclusion and marginalization rates in many countries. The globalization is a process that aims to impose a domination of markets and culture, in a worldwide-connected system and in a unique perspective. The mass media impose 
ways of controlling the society, market organization and consumption as a way to control people's lives, their ways of being and doing things. There are senses and meanings imposed, charged with representations, beliefs and symbolic values associated with the consumption of material goods, not only for basic needs, but other needs imposed as a way of social recognition.

The transmission, conservation, transformation and learning of a culture happen through social practice that, in turn, is organized according to discursive processes. According to Pais (2007), knowledge and meaning are articulated in the process of discursive production and reflect the worldview and the value system built in the historical process of a community.

This paper is aimed to describe the partial results of a project developed and conducted by professors and researchers in Public Policies, with young students of a technical public secondary education school (high school) in Mogi das Cruzes, São Paulo state, Brazil.

Today it is possible to recognize values that are built in discursive process in social media, which, in turn, produce senses about sustainability, environment, consumption and culture, which are presented in globalized contemporary social practices and used social media for sharing experiences. The Web 2.0 has shown means of registering environmental and cultural heritage, especially as seen in videos made by users in the social media YouTube.

The results show the importance of the formation of youth in the scientific-cultural activities in the university. In order to get all these students responsible for their work, they were invited to present their research to graduating and post graduating students. This was, a way to other students could understand the importance of the research about the regional diversity and local cultural policies that require a closer look at the closer reality.

Such project had its origin in discussions about ways for the improvement of the Brazilian basic education quality. In this sense, it was thought in the political and scientific-cultural formation as an initiation project focused for heritage and culture registering daily facts, catching ideas, becoming a filmmaker and a YouTuber. It can highlight the participation in social actions and how these videos, available on YouTube can register local culture as an exercise.

\section{The Use of YouTube in Preserving Cultural Memory >a Heritage Education Strategy}

Social Networks are the result of the technology which runs globalization and presents new settings, whose extension, from the last decades, has boosted cultural, social, economic and political changes which interfere in the ways of being, thinking and doing, in an individual or collective level, especially, in the sense of recording the memory of knowledge and practices.

The cultural and economic integration, supported by the improvement of social media, has boosted new ways in the centralization and organization of the capital, which 
favors the creation of new injustice settings and inequalities, which further aggravated poverty rate, exclusion and marginalization in several countries, thus: globalization expresses a very complex process that involves economic issues, cross cultural approaches and political entanglement (Pieterse, 2015).

In this way, the process of globalization in which we operate, disqualifies people and peripheral cultures in order to suppress the local cultural expressions, with the establishment of new values, heroes, symbols etc., or a new way of living life where "The world becomes 'one' and, depending on how this new reality will be addressed, will foster social cohesion or increase the exclusion in a higher level" (Gomes-Granel \& Vila, 2003: p. 19).

It is in this context the local cultures have been weakening, because the communities which, in great part, were instituted only by territorial delimitation, today transcends spatial limits, with the consolidation and expansion of Networks and virtual communities, which allows people to participate in the communities where the spatial boundaries were surpassed.

Hall (2006) argues that globalization have been weakening national culture and local identities due to intense cultural infiltration that triggered the fragmentation of cultural codes, which allowed a more intense presence of the ephemeral, floating, perspective that dominated the postmodern global which brought great consequences, among them, so according to Hall (2006: p. 74) “...national cultures become more exposed to external influences, is difficult to maintain intact cultural identities or prevent them to become weakened through the flood of cultural infiltration.

Relationships and bonds that guided the life and relationships between people who shared a common territorial area, formerly structured through joint actions and cooperation, now are called as extraordinary actions, or as exceptions. As a result, the local culture is shown in: tangible ways, through buildings, squares, monuments, etc., and in intangible ways, through parties, beliefs, etc. which have lost their value in the communities where they started, opening space to the strengthening of a globalized culture and the entertainment culture.

It is, according to these principles and reality and their political-social and socialcultural discourse, proposed a reflection about the local culture and its scholar education in the primary level, as a way to recognize its importance in the formation of future generations and strengthen local identities as well as to foresee the development of critical pedagogy through the study of artistic manifestations and material and immaterial heritage, manifestations, or even by unveiling the communities where schools are inserted.

According to Flecha (1996: p. 36), prioritized knowledge by the new social organization is distributed unfairly among the various segments of population following the criterion of race, gender, social group, etc. Such layout, besides being excluding and only exploit the necessary knowledge for the maintenance of the status quo, disqualifies the knowledge of marginalized sectors, "[...] even if they are richer and more complex than the prioritized". 
This process, by giving more to the ones who have more and less to the ones who have less, according to the author, sets up a closed circle of cultural inequality, which constitute of three phenomena: distinction, segment and systematic colonization of the world, of life (Flecha, 1996). The first phenomenon presented by the author, called distinction, refer to the sectors that occupy privileged social positions, which also have the power of decision of which culture must be valued within their social environment, being so, in its regulation.

[...] Converge both the criterion of what results to be functional for the social development, as well as the criterion of what these sectors are allowed to be exclusive holders of such knowledge. [...] The privileged sectors more and more determine their cultural habits according to their symbolic power of knowing the difference in relation to the rest of population (Flecha, 1996: p. 36).

It is in this context that knowledge and cultural practices, valued in great part by formal education, were being set up, especially in public schools aimed at popular classes, which seek to prioritize a formation supported only in the language development and logical reasoning. This kind of thought leads to an education for the labor market, that can be seen as a process that is accompanied by disqualification and depreciation of culture and tangible and intangible heritage of local communities.

This scenario intensifies even more what Barbosa (1998: pp. 14-15) called "cultural apartheid" seen in schools: "Lower class culture continues to be ignored by educational institutions. [...] Social mobility depends on the inter-relation between the cultural codes of different social classes.

An education must be by such principles in order to provide a critical reading about inequalities and new ways of exclusion in the information/knowledge society. A kind of education, which adopts new methodologies that can prioritize the human nature and local culture, is needed. There is a conception that influences several teaching systems, which aims to select the "best", in order to form workforce to the labor market. In this context, access, retention and quality of education are not the same, because a small portion of the population has the access to a high quality education. According to Flecha (1996): "Every person has one head, but not all of them can afford to have access to privileged information".

By imposing a culture as the only validation path, the privileged sectors determine the ways of being in the world. As Flecha (1996) thoughts: the magic of the status and the desire to be accepted that leads great part of the population to experience social-cultural practices of the privileged sectors. The same occurs to the consumption, encouragement that can distance individuals from certain values and attitudes supported by ethics. Not only this, but having goods and be present at cultural manifestations, usually set by the society of spectacle (Debord, 2002), which stimulate a momentary and superficial approach of a given culture as "superior" and unattainable for most of the population.

Such questions circulating intensively in the scholar environment in two dimensions: on one side, by the intensification of consumption desires through things, clothing etc., 
on the other side, by their own selected knowledge as priority, which imposes an official culture in a curricula that strengthen the ideological bias that supports and strengthens the globalized capitalist system in which: instead of promoting a critical reflection and human comprehension, the dominant curriculum model emphasizes the logical probability as the main definition of truth and meaning. The concepts, which characterize this model, seem not to be only less critical: they are blank checks that support the status quo (Giroux, 1997: p. 47).

As a consequence, such reality led to the consolidation of a merely instrumental scholar formation that, in addition to disregarding the culture and local heritage. In this way, the local culture ended up being neglected, which vanishing the feeling of belonging to a small group, because it is not valid anymore.

According to Flecha (1996: p. 38), the desire for cultural democratization which tends to get tied up to a dynamics that mixes the educational resources and expand in various times and spaces, thus "the process of bureaucratization and academicism is not limited to the scholar system; it is also seen among professionals...”. For the author, the people's rights to the culture and knowledge also comprise the fight against this "engineering mentality" aimed to colonize social and private life, point of view seen in most of the cultural institutions in the contemporary world.

\section{Method}

If on one hand the ease of communication allowed such comfort to the access hitherto unimaginable, with such ease of communication virtual communities have broken territorial boundaries, on the other hand, we noticed that the decrease between distance has been gradually isolating people and taking them away from life in their local community, neighborhood. In this sense, it was thought the possibility of approximate people, arousing the feeling of belonging through videos available on YouTube.

Konjin, Veldhins, \& Plaisier (2013) state that YouTube settings offer different opportunities of research, not only about the effects of the various contents, but also the variety of profile users who post their home videos, once it is possible no analyze nicknames and take a demographic data raise.

So, in 2014, the authors invited researchers in Mogi das Cruzes, São Paulo Brazil, young students in a high school and his teachers of History and Philosophy, to develop a research Project about cultural issues around them in this chosen city.

The students produced the project in two stages: 1) a field research by recording images and videos about local issues towards cultural diversity in the city. In order to know how to make a film, a video maker workshop was offered in the university facilities; 2) in television laboratory the students prepared their short videos; 3) their teachers created a channel on YouTube in order to upload all the videos. The channel was called Citizenship Dialogue and 31 videos were uploaded. As soon as the videos became on line the students were invited to participate in the videos evaluation. The evaluation began firstly in school. The students selected 8 videos. Only two videos were describe, here, out of eight, that participated in the exhibit, the choice of these videos was given 
for being well evaluated for their contents, by all assistants. They were chosen because they delimitated two characteristics of Mogi das Cruzes city: a) the role of Japanese in the local culture and $b$ ) the presence of graffiti artists supported by the local culture policies.

\section{Using YouTube Videos as a Teaching Methodology}

We understand that education is a permanent dialog with the living world: present, past and future. Thus, work, leisure, daily life and the space we occupy like streets, squares, monuments, parks etc., present in the communities where we live are ways that reveal our forms of being, living and doing things. This all are relevant issues for a scholar education in a critical perspective. The senses and meanings present in the local culture strengthen the individual and collective identities.

Such aspects demonstrate the necessity of expanding knowledge in the formal and non-formal education, which transcend the universal formal knowledge. They are essential for the formation of new generations, but in an isolated way do not guarantee reflections towards the issues affecting people's lives in a closer way and ways of sharing the world where communities live in. In this case these reflections was made using film making, a kind of look and see the city surrounding us. Translate the small universe of the city we live, we belong.

\subsection{Video 1: The Japanese Culture in Mogi Das Cruzes}

The video called the life of a mogiano student lasts 11 minutes and 16 seconds and talks about a real life history of 16-year-old teen, a Japanese farmers descendent. The teen helps his family in the local supply center, on Sundays, keeping his family's tradition for more than 5 decades. He and his family sell products straight from the producer. The story starts with the teen helping the loading of products on Saturday night, then it shows him waking up on Sunday morning at two o'clock, then he does all the chores along Sunday morning in the local producer supply center in Mogi das Cruzes, after that, it shows the tiring process of the student by doing chores of production, harvesting and study along the week.

This video shows the vision expected from high school students, since it is a proposal of expanded education, not only as formal education which is the one that answers the social and political demands of education, but it also shows itself to be a non-formal education which is a social responsibility (Figure 1).

Given this reality, there is the necessity to appreciate and potentiating local culture in the educational processes in the formal education in order to promote significant approaches towards cultural diversity and plurality of manifestation and material heritage seen in the neighborhoods, once:

In instantaneous contact times that unveil the world and put in check the old content and traditions, it is important to guarantee a space for discussion about uncertainties, which allow the flight to different times, but also recognizable to genuine expressions about knowledge and actions from each local culture, familiar or ethnic (Setúbal, 


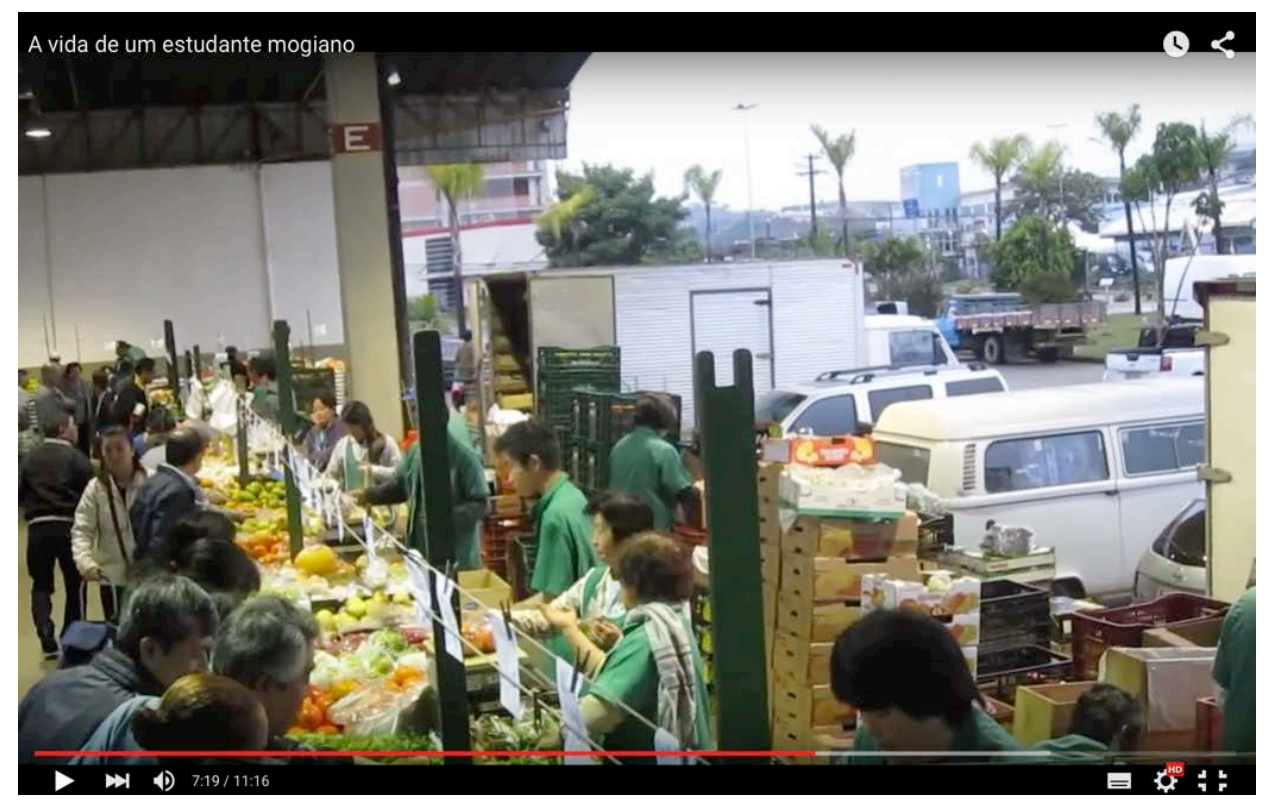

Figure 1. Print screen from the Video: The life of a Mogiano student. Source: https://www.youtube.com/watch?v=avry-Jfrgl8.

2010: p. 3).

It is in the city, neighborhoods, streets, or in the collective space where life is organized and enables attitudes, beliefs, values and knowledge to be presented in ways of being, existing and doing a certain symbolic, social, historical, and special context.

The local culture as focus on the education process cooperates to emerge and reveal community representations, which enhances comprehension and recognition of pattern and exclusion forms, since they strengthen identities and regional knowledge. It is expected that a development of a critical, sensitive and creative posture towards the society of consumption, dehumanization processes etc. By understanding the contemporary world and the culture of our community there is a possibility of comes out attitudes because the student/citizen, by gazing a new translation of the world that surrounds him/her.

Education, as seen from the legal discourse of the Brazilian law of education, since December 1996, and also presented in UNESCO report (Delors, 1998), highlights the following principles: responsibility about the knowledge from the cognitive civilization that is the basis of future competences. This report also inserts in this scope the social responsibility. Since then, educational policies are focused in a process of knowledge enrichment, as a privileged via of making the person himself/herself and, the relationships between individuals, groups and nations.

\subsection{Video 2: The Art on the Street: The Graffiti Expression}

The video Graffiti in the Alto Tietê and in the world, which lasts 6 minutes and two seconds, use other materials in video already available in social media to talk about the origins of graffiti. Then, the video is the product of field research of these students from 
the urban center of Mogi das Cruzes, mainly, when they talk about a well-known artist among citizens and local and regional media, known by doing graffiti about a dog called Lalalá Dog. Teens followed the artist and filmed him on act using spray and his colors giving form to his character and the sound is the record of the interview performed, expressing the way the artist understands the graffiti and disseminates his art (Figure 2).

\section{Heritage Education: Reflections on a Methodology Using YouTube}

Popular participation in different forms of recording and data access is fundamental to new ways of knowing, perceiving, criticizing, evaluating, and remembering. The computer is an external memory to the human, and the more the storage boundaries expand in clouds, the greater the possibility of production and content sharing in digital format in open access it will be.

Several cultures enable the citizenship education towards formal education that, in an integrated way, will constitute the universe of sense and meaning. That allows students to recognize themselves as subjects who inhabit a space, which was constituted at different times and under multiple influences and interventions, which, in turn, reveal ideas, values, beliefs, feelings, ways of living, working, coexisting etc. The use of YouTube, in order to have a look at the issue about cultural heritage around these students offered opportunities to spread they work, and there are spots, or takes from where they live. That is why is needed to conceive in the formal education, a dialog with local culture and the existing diversity.

The discourses are meaning networks and are inserted in a dynamic process and can

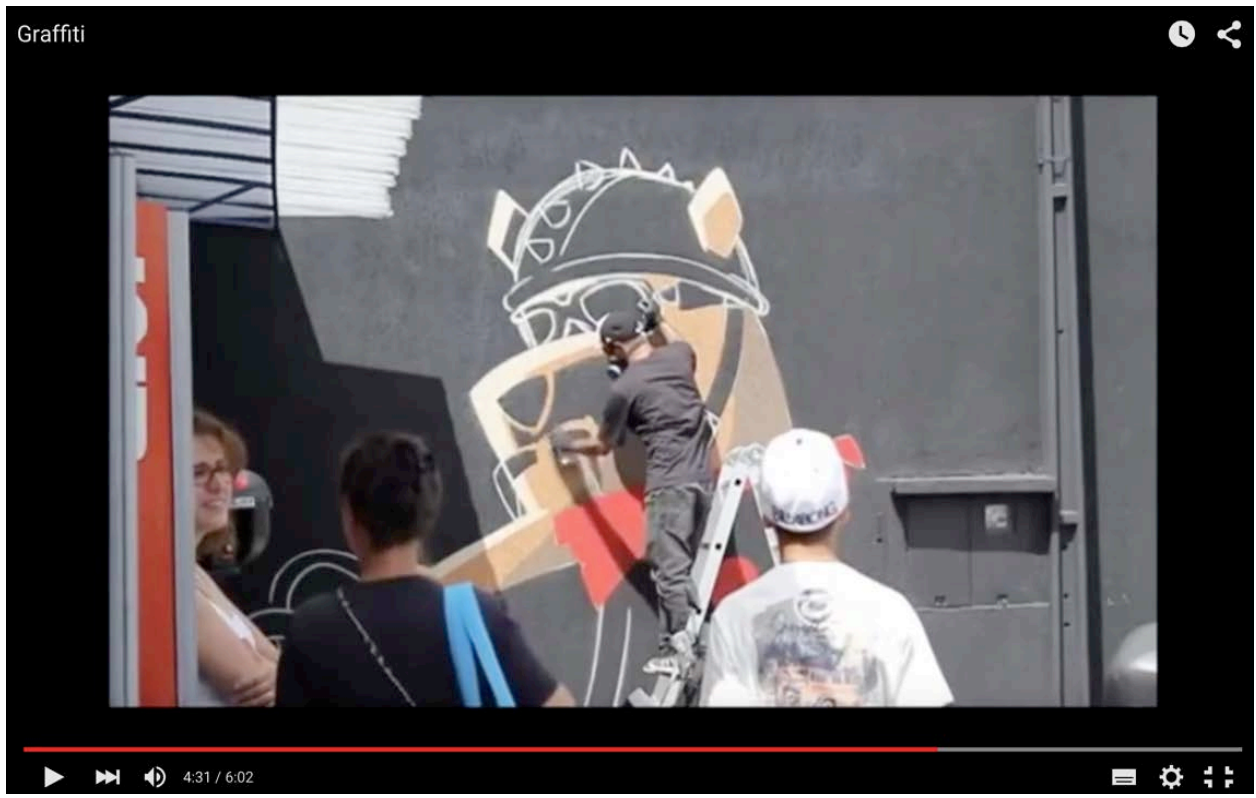

Figure 2. Print screen from the video Graffiti in the Alto Tietê and in the world. Source: YouTube (https://www.youtube.com/watch?v=y7LxWG0d9ig). 
be motivated by certain social fact, at certain time and space, and produce unique feelings in this specific context. Thus, educational policies are represented starting from the values expressed in documents and laws and these describe the new educational-political discourses.

In order to think about education in a contemporary society, towards social demands, anxiety and subject expectations it is necessary to think about the educational discourse that leads to a "...sense to the collective acts..." (Maingueneau, 2008: p. 138). In fact, the educational discourse, like all, is multiple and competes against others, and it is organized around strong texts, linked to institutions that guarantee their need for interpretation and authorization, according to Maingueneau (2008).

An education that goes beyond the ordinary, which is guided by maintenance of movement and permanency of the established, must be revised. In contrast to this trend, it is important defend an education, which searches the extraordinary, which aims to break the order and proposes new alternatives on the ways of being, thinking and doing, under new patterns, which are in balance with the principles of a democratic society.

It is in this context that the local culture, the tangible and intangible heritage of local communities, are presented as important elements for reflection on the external stimuli of living, experiences and representations that students are exposed.

Oliveira \& Wenceslau (2007) understand that Educational Heritage should be addressed at the context of basic education in order to provide the knowledge and meanings to students related to tangible and intangible materials in historical, cultural or natural context, through the approaches and experiences that arouse curiosity, interest and works for raising awareness about local, regional and national identity.

It is worth remembering that Heritage education should not be worked as a way of demanding identity, but included as a trigger, which is done by:

[...] a starting point, presenting, arguing and generating, in each individual, the necessity, the interest in wanting to get identified with the heritage, only presenting grants so that it can see inside its community the heritage which is meaningful in its identity (Oliveira \& Wenceslau, 2007: p. 31).

In this sense, the Heritage Education plays a key role in overcoming the hegemonic perspective, mass culture and imposed spectacles in postmodernity. As referring to ideals, activities and knowledge of local communities, Heritage Education is opposed to the fluidity, the inconstancy and superficiality in the modern world, which has its largest consumption reference.

A critical Heritage education is a way of developing the students' commitment with their preservation for their enjoyment and future generations of a cultural heritage relevant to their community, neighborhood, city etc.

The perspective of an education that starts from a critical analysis from the reality aiming to change it provides the overcoming of several lacks existing inside the single assimilation of contents for a pedagogical action. It is important to figure out how to develop a critical posture towards culture from your community, as it encourages the 
students' participation and responsibility towards cultural goods and heritage.

We highlight the methodological proposal towards the Heritage Education structured by Horta (1996: p. 6), who proposes four inspirational stages for this research:

o Observation-data and information about the object of study in question is raised in this stage;

o Recording-after raising the relevant issues about the heritage in study, which is carried out through various teaching procedures and languages, the deepening of the reflections from the previous stage through written and/or oral descriptions, models, tridimensional designs, photographs, videos etc.;

o Exploitation-when critical analysis is performed from the raised heritage, which is carried out through reflections, debates, evaluations etc., using various sources of searching like libraries, sites, newspapers, magazines, historical documents, photographs etc.;

o Appropriation-it consists of the final stage of the process, along with increased knowledge about the object of study, which provides emerging senses and meanings for validation and recognition (or not) of the covered heritage.

In this process, some caution should be observed, Oliveira \& Wenceslau state that (2007: p. 32), the Heritage Education is not only aimed to encourage the conservation and retaining of physical spaces and cultural objects, like buildings, squares, monuments etc., or events like parties, costumes etc.; but also to rescue the memory, senses which lead to a particular community to recognize these elements as legitimate heritage of a collective with which it is identified, in order to:

[...] Rescue the relationship of affection between the community and its heritage, establishing between them an approaching process making the community have a belonging feeling in relation to their heritage, wishing thus its rescue and preservation (Oliveira \& Wenceslau, 2007: p. 32).

The ability to create content on social networks, like YouTube, brought, indiscriminately, several ways to use multi languages offered by the Web 2.0 to register responsive actions. The recording and documentation of cultural, social movements, dissemination of information have been growing in social networks and strengthen when Web 2.0 appeared. The advent of new scanning technology and digital reconstruction, as well as their applications has revolutionized the ways to archive and store different human actions (Pavlidis et al., 2004).

For such, it is necessary to develop methodologies which allow the overcoming of common sense view on culture and local heritage through an educational proposal, that provides students the perceptions and meaningful experiences related to the space where they live, or other representations that interfere in any other way in the ways of being and individual acting and from collective to which it is related.

\section{Conclusions}

The popular participation in different ways of registering and accessing to data is crucial to new ways of knowledge, perceiving, criticizing, evaluating and remembering. 
The computer is an external memory to the human, and the more the boundaries of recording are expanded on clouds, the greater the possibility of production and sharing contents in digital form in open access is.

Also, it is important to consider that, the link between educational work within the formal education in an educating city demands a greater system, which favors the dialogue, linking with other non-formal educational agents, in our case, with institutions, spaces and existing acts in the community, in the neighborhood, in the city, democratizing the access and enjoyment of the cultural heritage, providing students with a citizenship formation.

Therefore, it is necessary that the education can deal with the heritage and local culture from the establishment of the pedagogical project of the school. A critical pedagogy at the cultural heritage is expected to promote permanent dialogue with the area, the city, the neighborhoods and communities as a form of ownership of the people and their participation in the proposals for the spaces in which they live.

The school should be considered as a space where various cultures take place, among which is the experiential culture, which is the result of local culture. This process is related to the individual and the world where he lives in and the interpretation schemes and meaning established along with the local culture. Thus, meaning from all experiences is relevant in pedagogical aspects, because they revere the local culture and its interaction with the academic culture.

Such questions highlight the necessity to establish different methodologies that can enhance the development of actions and/or educational projects allied with technologies of information and communication so that students can own this rich universe of meanings.

The students must have direct contact to the spaces in his/her neighborhood, in his/her city, in order to be closer to buildings, works, art products, social and historical values from different times, which are important elements of tangible and intangible heritage.

\section{Acknowledgements}

The authors thank CAPES: Coordenação de Aperfeiçoamento do Pessoal de Ensino Superior for the support for this research and FAEP: Fundação de Amparo aoEnsino e à Pesquisa.

\section{References}

Barbosa, A. M. T. (1998). Tópicos utópicos. Belo Horizonte: C/Arte.

Delors, J. et al. (1998). Learning: The Treasure Within. Unesco Publishing.

Debord, G. (2002). The Society of Spectacle. Canberra: Hobgoblin.

Flecha, R. (1996). As novas desigualdades educativas. In M. Castells, (Org.), Novas perspectivas críticas em educação. Porto.

Giroux, H. A. (1997). Os professores como intelectuais: Rumo a uma pedagogia crítica da aprendizagem. Porto Alegre: Artmed. 
Gomes-Granell, C., \& Vila, I. (2003). A cidade como projeto educativo. Porto Alegre: Artmed.

Hall, S. (2006). A identidade cultural na pós-modernidade. Rio de Janeiro: DP \& A.

Horta, M. L. P. et al. (1999). Guia básico de Educação Patrimonial. Brasília: IPHAN/Museu Imperial.

Pieterse, J. N. (2015). Globalization and Culture: Global Mélange. Rowman: Littlefield.

Konjin, E. A., Veldhuis, J., \& Plaisier, X. S. (2013). Youtube as a Research Tool: Three Approaches (Vol. 16, pp. 695-701). Amsterdam: Department of Communication Science, VU University.

Maingueneau, D. (2008). Cenas da Enunciação. São Paulo: Parábola Editora.

Oliveira, F., \& Wenceslau, F. F. (2007). Educação Patrimonial e a pesquisa arqueológica do sítio “Casa de David Carrabarro". In A. L. Soares, \& S. C. Klamt (Org.), Educação Patrimonial: Teoria e prática. Santa Maria: Ed. UFSM.

Pais, C. T. (2007). Considerações sobre a semiótica das culturas, uma ciência da interpretação: inserção cultural, transcodificações transculturais. In RevistaActa Semiótica et Lingvistica (Vol. 11, pp. 149-157), Sociedade Brasileira dos Professores de Língua Portuguesa. São Paulo: Terceira Margem.

Pavlidis, G. et al. (2004). Archiving Cultural Objects in the 21st Century. Journal of Cultural Heritage, 5, 379-384. http://dx.doi.org/10.1016/j.culher.2004.04.001

Setúbal, M. A. (2010). Viver e valorizar o novo e a tradição. In Educação e cultura. Cadernos Cenpec/Centro de Estudos e Pesquisas em Educação, Cultura e Ação Comunitária. N.7. São Paulo: CENPEC. http://dx.doi.org/10.18676/cadernoscenpec.v5i7.53

Submit or recommend next manuscript to SCIRP and we will provide best service for you:

Accepting pre-submission inquiries through Email, Facebook, LinkedIn, Twitter, etc.

A wide selection of journals (inclusive of 9 subjects, more than 200 journals)

Providing 24-hour high-quality service

User-friendly online submission system

Fair and swift peer-review system

Efficient typesetting and proofreading procedure

Display of the result of downloads and visits, as well as the number of cited articles

Maximum dissemination of your research work

Submit your manuscript at: http://papersubmission.scirp.org/

Or contact ce@scirp.org 